\section{Tietoa kansalle!}

Koskinen, lina, Ruuska, Maria \& Suni, Tanja (2018). Tutkimuksesta toimintaan. Tieteentekijän opas viestintään ja vaikuttamiseen. Art House. 264 sivua.

TIETEELLINEN TUTKIMUS elää osana laajempia yhteiskunnallisia, kulttuurisia ja poliittisia toiminnan piirejä, mutta se on myös omalakisensa systeemi, jota ei voi jäännöksettä palauttaa mihinkään muuhun toiminnan kenttään.

Selkeimmin tämä omalakisuus näkyy siinä, että tieteellisen tiedon odotetaan perustuvan laajaan ja kriittiseen analyysiin, jossa tutkittavaa ilmiötä on koeteltu eri näkökulmista. Ei riitä, että tutkija luulee tietävänsä tai on intuitioonsa perustuen mieltä tutkimastaan kohteesta.

\section{TUTKIJAN NISKA PAINUU}

\section{KUMARAAN}

Tutkija kuin tutkija tunnistaa ja tunnustaa tutkimukselle asetetut vaateet omakohtaisiksi, oli tieteenala mikä tahansa. Itsestään selvää tutkijoiden piirissä on sekin, että tutkimustulokset pitää saatta julki. Tuloksia ei ole, jos niistä ei kerrota - tiedeyhteisölle viestiminen kuuluu itsestään selvästi asiaan.

Tutkijan niska saattaa kuitenkin painua kumaraan, kun tutkija kohtaa nykyään yleisen vaateen kertoa tutkimuksestaan ja sen tuloksista laajemmille yleisöille, parhaimmillaan tai pahimmillaan niin sanotulle tavalliselle ihmiselle asti.

Vähintään pitää osata kertoa yhteisisistä asioista päättäjille, että

he osaavat tehdä tietoon perustuvia päätöksiä. Kertoa pitää, vaikka ei ole ollenkaan varmaa, kuunnellaanko, luetaanko, ymmärretäänkö, piitataanko. Voi tutkijaparkaa.

\section{TUTKIMUKSESTA TOIMINTAAN}

Tutkijan ei kuitenkaan tarvitse selvitä viestinnän kiemuroissa yksin. Työkaluja ja neuvoja on tarjolla, jos niihin osaa tarttua. Yksi käypäinen apuväline on Tutkimuksest toimintaan, jossa kerrotaan selkeällä suomen kielellä tiedeviestinnän peruskikoista.

Keinot esitellään yhdeksässä sujuvasti kirjoitetussa ja erittaiin hyvin kustannustoimitetussa luvussa. Ne ovat 1) Tunnista tutkimuksesi mahdollisuudet, 2) Viesti ja vaikuta suunnitelmallisesti, 3) Tuota laadukasta sisältöä eri viestintäkanaviin, 4) Opettele tekemään yhteistyötä median kanssa, 5) Kutsu sidosryhmät mukaan, 6) Järjestä innostavia tilaisuuksia, 7) Vaikuta päätöksentekoon, 8) Ota yrityshteistyöstä kaikki irti ja 9) Seuraa tutkimuksesi vaikuttavuutta.

Kunkin luvun lopussa on teeman ydinkohtia kertaavia muistilistoja ja teemaa havainnollistava haastattelu. Sinne tänne sirotelluissa tietolaatikoissa tarjotaan täsmällisemmin neuvoja eri teemoista.

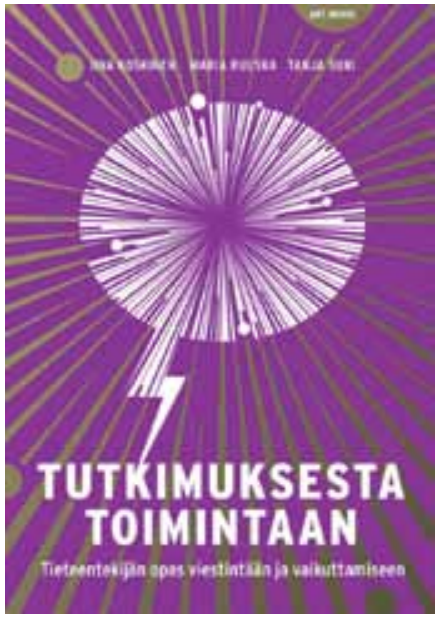

SULOSANAILUN NURJA PUOLI

Ikinä aiemmin en ole päässyt torumaan kirjoittajia liian taitavasta sanailusta, mutta nyt sekin päivà näemmä koitti. Neuvot näet tarjotaan erittäin lukijaystävällisesti, suorastaan siloisesti. Tekstiä on lo lukea: se soljuu sujuvasti, niin, että ajatus ei oikeastaan pysähdy mihinkään. Tämä ei ole ihme, sillä tekijät kustannustoimittajaansa myöten ovat tiedeviestinnän konkareita, tietävät konstit ja osaavat niitä käyttää.

Mutta sulosanailun jälkisointu haihtui koko lailla pian, enkä ole ihan varma siitä, ovatko tekiät kuitenkaan halunneet käyvän niin. Ennemminkin arvelen, että ammattilaisina he ovat halunneet nostaa esiin niitä kiperiä kohtia, joita tutkija joutuu kohtaamaan astuessaan itse tutkimuksen maailmasta itselle ehkä hiukan vieraampiin maisemiin.

Tutkijayhteisölle viestiminen on jokaiselle tutkijalle perus-
NeUVOT TARJOTAAN

SUORASTAAN SILOISESTI.

kauraa, ja jonkin verran jokainen joutuu kertomaan tekemisistään myös laajemmalle akateemiselle yhteisölle. Sen sijaan niin sanotulle laajalle yleisölle asioista kertominen voi olla hyvinkin hankalaa, minkä tekijät tuovat kyllä sanojensa tasolla esiin useaan otteeseen. Silti viesti jää kellumaan.

Konkreettisten hankalien tapauksien esittely kaikessa karuudessan olisi saattanut tuoda tutkijan todellisuuden vielä lähemmäs lukijaa, antanut samastumiskohteita. Nyt haastatteluissakin painotetaan onnistumisia Niitä korostamalla lienee tarkoitus todista kirjan tärkeintä sanomaa: tutkij voi viestiä ja vaikuttaa Niin no, tottahan se on, en väitä vastaan.

RIITTA KOIKKALAINEN

YTM, tietoasiantuntija erityisalana tieteellinen julkaiseminen,

tiedetoimittaja

Kirjastoverkkopalvelut

\section{Aikuiskasvatus}

\section{avoimeksi}

Aikuiskasvatus ilmestyy ensi vuodesta ähtien avoimena ja maksuttomana. Tallenna kirjanmerkkeihisi oikeat osoitteet ja liity lehden seuraan vuonna 2019.

- Journal.fi-palvelussa voit lukea Aikuiskasvatusta ilmaiseksi tuoreeltaan. Palvelussa on kuutisenkymmentä avointa tiedelehteä: www.journal.fi/aikuiskasvatus.

- Aikuiskasvatuksen verkkosivuilla voit lukea blogia, seurata tieteenalan kuulumisia ja perehtyä kirjoittajaohjeisiin ja olla yhteyksissä toimitukseen:

www.aikuiskasvatus.fi.

- Seuraa tviittejä tiedetapahtumista tai viritã keskustelu: https://twitter.com/aikuiskasvatus.

- Kasvatuksen tiedelehtien yhteisellä foorumilla voit seurata viittä tiedelehteä: www.facebook.com/kasvatuksentiedelehdet.

- Booky-verkkokaupasta voit ostaa lehden aiempia numeroita: www.booky.fi.

- Aikuiskasvatuksen Tutkimusseurasta voit tiedustella mahdollisuutta tilata lehti painettuna: ats.sihteeri@gmail.com. 